\title{
Nodal and Extranodal Peripheral T/NK-Cell Neoplasms: Current Aspects
}

\author{
Ivan Petković1,2, Aleksandar Popović ${ }^{2}$, Miljana Džunić2, Ivica Pejčićc ${ }^{1,2}$ \\ ${ }^{1}$ University of Niš, Faculty of Medicine, Department of Oncology, Niš, Serbia \\ ${ }^{2}$ Oncology Clinic, Clinical Center Niš, Niš, Serbia
}

SUMMARY

Peripheral T/NK-cell lymphomas (PTCL) are rare, bizarre, and extremely diverse cancers. The disease is prone to relapse with a high level of chemorefractoriness leading to a poor outcome. Almost $70 \%$ of patients will experience relapse, with a median 5-year overall survival (OS) in approximately $30 \%$. Upfront management of PTCL has been extrapolated from the treatment paradigm for aggressive B-NHL. However, universally accepted induction is rather palliative than curative. Regardless of the maximal reinforcement of upfront management, only event-free survival has been influenced but not the OS. All actual guidelines emphasize the importance of the autologous stem cell transplantation (auto-SCT) as a consolidation of first major response. The allogeneic SCT (allo-SCT) is not evidence-based part of upfront management. Nevertheless, its use is justified in the relapsed/refractory setting. Unfortunately, the vast majority of patients are not candidates for aggressive treatment modalities making the recommended paradigm as limited feasible. Regarding such a situation, novel compounds are warranted. Although presented data indicate ominous prognosis in PTCL, it is important to denote that there has been evidence - based improvement in the treatment paradigm by the introduction of L-Asparaginase and targeted therapy for CD30+ PTCL. In this sense, a considerable number of new compounds entered early phase trials and gave promising results. All lights have been focused on upcoming results given the fact that at the moment we have not much to offer to the patients who have relapsed or were primary refractory.

Key words: NK/T cell lymphoma, nodal, extranodal, treatment, new agencies

Corresponding author:

Ivan Petković

E-mail: ivan.petkovic@medfak.ni.ac.rs 


\section{INTRODUCTION}

T/NK -cell neoplasms include T-cell and NKcell lymphomas/leukemia originating from postthymic T-cells or mature NK-cells. Considering the presumed cell of origin, the unified denotation for all entities is peripheral T-cell lymphomas (PTCL).

PTCL represents a rare and extreme heterogeneous class of lymphoproliferative neoplasms with predominant aggressive clinical behavior leading to a poor outcome. According to the pattern of neoplastic cell growth and tumor burden distribution, PTCL are distinguished as nodal, extranodal, and leukemic. Primary cutaneous NK/T-cell lymphomas (CTCL) are extranodal by their nature, but are considered as distinct entities. Leukemic transformation of primary extranodal or rarely nodal PTCL may occur during disease natural course. All PTCL have been summarized according to the latest revised version of the World Health Organization (WHO) classification of NK/T-cell neoplasms (2016) in Table 1.
These types of lymphomas are rare indeed and account for less than 10-15\% of all non-Hodgkin lymphomas (NHL) among adults (1). Striking geographical and racial variation in incidence is the major epidemiological hallmark of PTCL $(1,2)$. Recent studies have identified recurrent mutations and new insights in the genetic landscape of PTCL, leading to the definition of new provisional entities (3).

Comprehensive clinical data point to poor prognosis across all subtypes of nodal/extranodal PTCL and in most of the primary leukemic entities. The treatment paradigm includes aggressive systemic therapy accompanied with autologous stem cell transplantation (auto-SCT) as a consolidation of the first remission in almost all PTCL entities. However, even highly effective as an induction setting, such an approach have limited applicability for the majority of patients considering transplant eligibility and long-term survival. Upfront allogeneic SCT (allo-SCT) is not recommended outside clinical trials, except perhaps in HSTCL. Its place has been

Table 1. Nodal, extranodal and leukemic NK/T-cell neoplasms WHO 2016

\begin{tabular}{|c|c|c|}
\hline Nodal & Extranodal & Leukemic \\
\hline $\begin{array}{l}\text { Peripheral T-cell lymphoma, not otherwise } \\
\text { specified (PTCL-NOS) }\end{array}$ & $\begin{array}{c}\text { Extranodal NK/T-cell } \\
\text { lymphoma, nasal type and } \\
\text { extranasal type (ENKTCL) }\end{array}$ & $\begin{array}{l}\text { T-cell prolymphocytic } \\
\text { leukemia }\end{array}$ \\
\hline \multirow[b]{2}{*}{$\begin{array}{c}\text { Nodal T-cell lymphoma with T-follicular } \\
\text { helper (TFH) phenotype: }\{\text { Angioimmunoblastic } \\
\text { T-cell lymphoma (AITL), Follicular T-cell } \\
\text { lymphoma, other nodal PTCL with TFH } \\
\text { phenotype }\end{array}$} & $\begin{array}{c}\text { Enteropathy associated T- } \\
\text { cell lymphoma type I (EATL) }\end{array}$ & \multirow{2}{*}{$\begin{array}{c}\text { T-cell large granular } \\
\text { lymphocytic leukemia } \\
\text { *New subtypes recognized with } \\
\text { clinicopathologic associations } \\
\text { *STAT3/5 mutations associated } \\
\text { with more aggressive clinical } \\
\text { course }\end{array}$} \\
\hline & $\begin{array}{l}\text { *Indolent } T \text {-cell } \\
\text { lymphoproliferative disorder of } \\
\text { GI tract } \\
\text { (provisional entity) }\end{array}$ & \\
\hline $\begin{array}{c}\text { Anaplastic large T-cell lymphoma, Anaplastic } \\
\text { lymphoma kinase positive (ALCL,ALK+) }\end{array}$ & $\begin{array}{c}\text { Monomorphic } \\
\text { epitheliotropic intestinal T- } \\
\text { cell lymphoma (MEITL) } \\
\text { *Former EATL type II }\end{array}$ & $\begin{array}{l}\text { Chronic lymphoproliferative } \\
\text { disorder of NK-cells }\end{array}$ \\
\hline $\begin{array}{c}\text { Anaplastic large T-cell lymphoma, Anaplastic } \\
\text { lymphoma kinase negative (ALCL,ALK-) *6p25 } \\
\text { (IRF4/DUSP22) } \\
\text { rearrangement-better prognosis }\end{array}$ & $\begin{array}{l}\text { Hepatosplenic T-cell } \\
\text { lymphoma ( } \gamma \delta \mathrm{T} \text {-cell, very } \\
\text { rare } \alpha \beta \mathrm{T} \text {-cell) (HSTCL) }\end{array}$ & $\begin{array}{l}\text { Aggressive } \mathrm{NK} \text {-cell } \\
\text { leukemia }\end{array}$ \\
\hline \multirow[t]{2}{*}{$\begin{array}{l}\text { Breast implant-associated anaplastic large T- } \\
\text { cell lymphoma (BIA-ALCL) }\end{array}$} & & $\begin{array}{c}\text { *Systemic EBV-positive T- } \\
\text { cell lymphoma of childhood } \\
\text { *Former lymphoproliferative } \\
\text { disorder }\end{array}$ \\
\hline & & $\begin{array}{c}\text { Adult T-cell leukemia/ } \\
\text { lymphoma (ATLL) }\end{array}$ \\
\hline
\end{tabular}


reserved as a salvage of relapsed disease, if applicable. The clinical significance of allo-SCT relies on graft versus lymphoma/ leukemia (GvL) effect and immunologic maintenance $(4,5)$. Presuming that allo-SCT allows survival curve shift to significant survival advantage, the question of its applicability remains opened due to a lack of prospective randomized cohorts to which it will be of the most benefit, i.e. when is the right moment to proceed with the procedure is, with reference to its aggressiveness.

Relapsed/refractory (R/R) PTCL is the most challenging setting in the treatment schedule given the fact its undefined management and extremely poor outcome. A numerous compounds have been released in early clinical phase trials with promising results. Nevertheless, no substantial improvement has yet been made. Emerging strategies including new agents in upfront setting or remission-maintenance therapy are warranted.

\section{BACKGROUND, ETIOLOGY AND EPIDEMIOLOGY}

The tail about PTCL is covered with a veil of mystery and uncertainties given their bizarre clinical characteristics, rarity, and diversity. The most of randomized trials in this field of oncology have been conducted for nodal counterparts. Extranodal and leukemic subtypes have a lack of phase III trials regarding their rarity, or even more a quite number of entities are exclusively rare and clinical data are reduced to the extent of a single center experience and case reports. In general, etiologic and clinical background of T/NK-cell NHL is less well understood than of B-cell NHL.

The pathogenesis of PTCL remains generally unknown. The Epstein-Barr virus (EBV) is one of the most incriminated biologic agencies associated with PTCL pathogenesis. The EBV encoded RNA (EBER) has been detected by in situ hybridization of paraffin embedded sections in a majority of cases, as well as membrane expression of the latent membrane protein (LMP) 1 and 2. It is supposed that the presence of RNA molecules may be in a part casually related to the disease development. In this sense, ENKTCL is one of the striking examples given the fact that almost $100 \%$ of cancer cells have been detected with EBER. However, the question if this is sufficient for the full cancer development remains unsolved.

It has been recognized that EBER positive PTCL-NOS, ALCL or other entities are associated with the worse clinical course over negative cases. Although HIV/ AIDS has been found to dramatically increase the incidence of aggressive B-NHL, the development of PTCL has been related with 15-fold increase among general population (6). Although HTLV-1 is associated with the pathogenesis of ATLL, other subtypes of PTCL entities have undetermined the significance of its presence. Nevertheless, it is recommended to perform a HTLV-1 test of its presence in patients with PTCL (4). EATL type 1 develops in the setting of preexisting celiac disease pointing to the cancerous influence of the condition. MEITL is found not to be related to a celiac disease suggesting its distinct developing mechanisms. HSTCL is associated in approximately $20 \%$ of cases with long-term immune suppression or chronic immune stimulation, due to autoimmune disease and medication used for its treatment (2).

Epidemiological data are pointing to the diverse geographical distribution of the PTCL across the world regions. In all published data, Asia and South America have been highlighted as a target point of the highest frequency (4). Regarding ethnicity, nodal counterparts are more often seen in Caucasians ( $>80 \%$ in Europe) with PTCL-NOS being the most common subtype with prevalence of $34 \%$, AITL 28\%, ALCL, ALK- 9\% and ALCL, ALK+ 6\% (1). The BIA-ALCL is a very rare subtype of ALCL. The risk of development in women with breast implants is estimated to range from 0.1 to 0.3 per 100.000 women with implants (7). In 2016, WHO enlisted BIA-ALCL as a new entity. On the other side, extranodal and leukemic counterparts are more often seen in Asia, where ENKTCL is a predominant subtype due to the endemic EBV infection with the incidence of $44 \%$ among all PTCL entities (1). EATL is more frequent in Northern Europe with a prevalence of $9-10 \%$ as compared to Asia with $1-2 \%$, due to a higher occurrence of incriminated HLA haplotype for coeliac disease. MEITL has a broader geographic distribution encountering Asia and other regions where coeliac disease is rare (2). HSTCL subtype is a very rare neoplasm accounting for less than $1 \%$ of all NHL. Peak incidence is in adolescents and young adults, with a male predominance and a median onset of 35 years (2). 


\section{DIAGNOSTIC STANDARD AND CLINICO-PATHOLOGICAL ASPECTS}

\section{Basic notifications}

Diagnostic management should rely on excisional tumor biopsy that provides enough material for formalin fixed samples. According to the revised WHO 2016, the distinction between different PTCL entities requires the integration of the clinical picture, morphology, immunohistochemistry, flow cytometry, cytogenetics and molecular biology (2). Novel data incorporated aberrant biomarker expression, clonally rearranged TCR genes $\alpha \beta$ vs. $\gamma \delta$ as standard, as the gene expression profile (GEP) and molecular clonal biomarkers will be part of the standard procedure in the near future $(3,8)$.

It has been clarified that NK and T-cells share common progenitor which is also the basis for the classification of NK/T-cell neoplasms as the entities to be considered together rather than separately. Basic adult (peripheral) $\mathrm{T}$-cell phenotype is determined by the presence of membrane CD3 as a sur- rogate of fully developed $\mathrm{T}$-cell receptor (TCR). Cytotoxic $\mathrm{T}$-cell profile is determined by the presence of membrane CD8 biomarker across with CD3, and cytotoxic granules perforin, $\mathrm{T}$-cell restricted intracellular antigen (TIA-1), and granzyme B in the cytoplasm. This phenotype implies more aggressive clinical behavior in PTCL-NOS subtype (9). However, recent findings have revealed variations in clinical behavior introducing low aggressive CD8+ $\mathrm{T}$-cell malignancies (10-12). NK-cells belong to a group of cytolytic cells that has effector activity in native immunity. These cells are marked by the NKcell associated markers such as CD16, CD57 with a CD56 being most consistently expressed $(13,14)$. The membrane CD3 is absent but the cytoplasmic expression of CD3 $\varepsilon$ chain, which is the most consistent finding in ENKTC, is present (15). Both types of cells express intracytoplasmic cytotoxic granules (16). The T-helper phenotype is determined by membrane CD4 biomarker expression across with CD3. Subpopulation of follicular helper T-cell (TFH), which

Table 2. The immunophenotype, TCR clonality and presumed cell of origin in nodal and extranodal PTCL subtypes

\begin{tabular}{|c|c|c|c|}
\hline PTCL entity & Most prevalent immunophenotype & TCR & Presumed cell of origin \\
\hline PTCL-NOS & $\begin{array}{c}\text { CD4>CD8, frequent antigen loss CD5, } \\
\text { CD7 , CD30+/-, CD56-/+, subset } \\
\text { FTH features, cytotoxic granules +/- }\end{array}$ & $\alpha \beta$, rarely $\gamma \delta$ & $\begin{array}{l}\text { Variabile, mostly } \\
\text { T helper cell }\end{array}$ \\
\hline AITL & $\begin{array}{c}\text { Pan T+, CD4+, CD10+/-, bcl6+/-, CXCL13+, } \\
\text { PD1+, ICOS+/-, SAP+/-, CCD5+/-, } \\
\text { hyperplastic FDRC, EBV+ B blasts }\end{array}$ & $\alpha \beta$ & FTH \\
\hline $\begin{array}{l}\text { ALCL, } \\
\text { ALK+ }\end{array}$ & $\begin{array}{c}\text { ALK+, CD30+, EMA+, CD25+, cytotoxic } \\
\text { granules+, CD4+/-, CD3+/- }\end{array}$ & $\alpha \beta$ & Cytotoxic T cell \\
\hline $\begin{array}{l}\text { ALCL, } \\
\text { ALK- }\end{array}$ & $\begin{array}{l}\text { ALK-, CD30+, EMA+, CD25+, cytotoxic } \\
\text { granules+, CD4+/-, CD3+/- }\end{array}$ & $\alpha \beta$ & Cytotoxic T cell \\
\hline $\begin{array}{l}\text { EATL } \\
\text { type I }\end{array}$ & $\begin{array}{c}\text { CD3+, CD7+, CD5-, CD8-/+, CD56-, HLA } \\
\text { DQ2/-DQ8 }\end{array}$ & $\alpha \beta$ & $\begin{array}{c}\text { Intraepithelial T cells }(\alpha \beta) \text {, pleomorphic, } \\
\text { preexisting enteropathy }\end{array}$ \\
\hline $\begin{array}{l}\text { MEITL, } \\
\text { (type II EATL, } \\
\text { formerly) }\end{array}$ & $\begin{array}{c}\mathrm{CD} 3+, \mathrm{CD} 7+, \mathrm{CD} 5-, \mathrm{CD} 8+, \mathrm{CD} 56+, \mathrm{MATK}+, \\
\text { HLA DQ2/-DQ8 }\end{array}$ & $\gamma \delta$ or $\alpha \beta$ & $\begin{array}{c}\text { Intraepithelial T cells or NK, } \\
\text { monomorphic, no-preexisting } \\
\text { enteropathy }\end{array}$ \\
\hline ENKTCL & $\begin{array}{c}\text { CD2+, CD56+, surface CD3-, cytoplasmatic } \\
\text { CD3e+, granzyme B+, TIA-1+, perforin+, } \\
\text { EBV+, LMP1+ }\end{array}$ & $\begin{array}{l}\text { In germline } \\
\text { configuration, } \\
\text { rarely } \alpha \beta \text { or } \gamma \delta\end{array}$ & NK, rarely cytotoxic $\mathrm{T}$ cells \\
\hline HSTCL & $\begin{array}{l}\text { CD3+, CD56+, CD4-, CD8+, CD5-, TIA1+, } \\
\text { granzyme M+, granzyme B-, perforin- }\end{array}$ & $\gamma \delta$ & $\begin{array}{l}\text { Cytotoxic } \mathrm{T} \text { cell of the } \\
\text { innate immune system }\end{array}$ \\
\hline
\end{tabular}


are located in germinal centers of lymph follicles as a subtype of CD4+T-cells included in B- cell maturation, is determined by minimum 3 biomarkers of the following: bc16, CD10, CXCL13, PD1, SAP, ICOS and CCR5 $(9,17,18)$. Aberrant expression of specific biomarkers is the hallmark of NK/T-cell neoplastic transformation. EBV infected neoplastic T/NK-cell are determined by the presence of LMP1/2, and EBER. All nodal and extrandal subtypes of PTCL with its specific immunophenotype and presumed cell of origin have been summarized in Table 2 .

\section{Clinical and pathological characterization of primary nodal PTCL entities}

Clinically, PTCL-NOS has no distinct features presenting as classic nodal NHL mostly in an advanced stage with B symptoms or paraneoplastic syndromes (eosinophilia, pruritus or haemophagocytic syndrome). Skin involvement is the most common extranodal manifestation of PTCL-NOS. Leukemic transformation is possible although rarely seen in clinical practice. Generally PTCL-NOS are highly aggressive neoplasms in most of the cases leading to poor outcome. It has been found that bone marrow involvement, EBV positivity, a high proliferative genetic signature, and cytotoxic granule expression correlate as negative prognosticators in PTCL-NOS $(9,19-21)$. The diagnosis of PTCL-NOS relies on cell morphology and particularly on immunohistochemistry by the exclusion of all other specifically defined PTCL entities. Currently, approximately $50 \%$ of T-NHL is not classifiable (22). Postulated cell of origin is mature T-lymphocyte, mostly CD4+ central memory type of adoptive immune system (2). Immunophenotype is usually characterized by CD4+, CD8- and the aberrant T-cell phenotype with down-regulation of CD5, CD7 or CD52. CD30 is found to be positive in some cases with a usually high Ki67 index. In most cases, TCR genes are clonally rearranged. PTCL-NOS usually refer to highly genetically aberrant neoplasm with complex karyotype. The broad spectrum of recurrent mutations have been determined both by conventional and array comparative genomic hybridization studies (2). However, none of these findings has clinical implementation. Novel molecular subgroups have been recently identified such as GATA3, TBX21 overexpression type and cytotoxic gene profile leading to new refinement of PTCL-NOS entity (22).
Clinical features for AITL include advanced stage lymphoproliferative disease encompassing generalized lymphadenopathy, hepatosplenomegaly, prominent B symptoms and polyclonal hypergammaglobulinemia (2). Skin manifestations such as rash or pruritus are frequently presented, as well as pleural effusion or ascites due to lymphoma progression. The patients typically exhibit progressive immunodeficiency leading to infectious complications or secondary cancer occurrence with the diffuse large B-cell lymphoma (DLBCL) being the most prevalent. All of the aforesaid indicate quite difficult aggressive treatment deliverance in patients with AITL. In general, AITL is an aggressive type of PTCL leading to poor outcome and median survival of less than three years. AITL has been identified as a neoplasm derived from TFH population according to biomarker expression (bcl6, CD10, CXCL13, PD1, SAP, ICOS, CCR5) (9, 23-26). Recent genetic recurrent mutations have been identified such as TET2, RHOA, IDH2, and DNMT3A in significant proportion of cases (27). It has distinctive morphological features characterized by polymorphous infiltrate containing medium-sized neoplastic cells, prominent arborizing high endothelial venules, and substantial portion of EBV infected B cell blasts (28). The presence of the infected $B$ cells may drive new cancer development on the basis of impaired T-cell immunity, particularly the DLBCL.

In more than $70 \%$ of cases, ALCL is in advanced stage nodal disease. Extranodal infiltrates are not uncommon, mostly presenting as bone marrow involvement or body cavity effusions, skin or involvement of other organs. ALK+ ALCL more often exerts extranodal features than ALK- counterpart. Skin ALCL represents the specific site of involvement which may progress in systemic, nodal form. Leukemic transformation although rare may be a part of the disease nature course more frequently in the ALK+ variant $(29,30)$. B symptoms are presented in most of patients. Small burden ALCL are a clinically favorable stage, especially if ALK+. Striking contrast in clinical outcome between ALK+ vs. ALK- has been widely defined. However, novel insights have been recently detected presenting ALK- ALCL as a heterogeneous disease with a subgroup carrying DUSP22/IRF4 rearrangement on chromosome 6p25 which lacks cytotoxic granules and seems to have a better prognosis in contrast to the previous view of the ALK- subtypes (31). 
ALCL is a neoplasm composed of mostly large cells with often "horseshoe"-shaped nuclei. ALK+ cases carry specific translocation $t(2,5)$ including nucleophosmyn-anaplastic lymphoma kinase (NPM-ALK) hybrid protein expression. Immunophenotype includes strong CD30 positivity of the membrane and the Golgi zone in almost all cases of both ALK+ and ALK- subgroup. Cytotoxic granules TIA1, granzyme B and/or perforin are detected in most cases.

BIA-ALCL is mostly in a form of peri-implant seroma, minimally one year after the surgery, but most commonly 7-10 years. Other rarer presentations are in a form of palpable mass or lymphadenopathy, and there have been reported cases of cutaneous lesion presentation (32-34). In case that these symptoms occur a year or more after surgery, in the absence of trauma or infection, BIA-ALTCL may be suspected. The first step is ultrasound, followed by aspiration of fluid, or biopsy in case of a solid mass. The disease is mostly with benign clinical course, particularly if localized. A typical finding includes CD30+ large anaplastic cells, and other pan T-cell markers.

\section{Clinical and pathological characterization of primary extranodal PTCL entities}

ENKTCL is an aggressive primary extranodal entity with a high predilection for the central face appearance. Former terms (lethal midline granuloma, angiocentric lymphoma, polymorphic/ malignant midline reticulosis) pointed to the disease specific body localization. Almost 2/3 of patients have localized disease in the nasal cavity or adjacent structures (oral cavity, pharynx) (35). However, in the remaining cases, the disease may appear extranasal primary or disseminate involving eyes, skin, larynx, intestinal tract, lung, testis or other (36). Lymph node involvement is uncommon at presentation but may occur in disseminated disease. Aggressive NK/T-cell leukemia may represent a leukemic counterpart of ENKTCL. Irrespective of the primary site of involvement, histomorphological picture is uniform with the domination of angiocentric and angiodestructive growth patterns. Fibrinoid vascular changes and coagulative necrosis with vascular occlusion by/ or without lymphoma cells are frequent (2). The neoplastic cells are pleomorphic in size and almost $100 \%$ EBV+. The immunophenotype is mostly of $\mathrm{NK}$-cell differentiation with
CD56+, CD2+, EBER+, and CD3- (membrane stain), while the CD3e chain is positive (cytoplasmatic stain) (2). There have been rare reports of $\mathrm{T}$ lineage markers' expression. No specific molecular mutations have been reported so far, although molecular test showed some recurrent mutations with unknown significance. The postulated cell of origin may be activated NK-cell or less common cytotoxic T-lymphocyte.

EATL and MEITL are an uncommon and rare diseases with the primary target in jejunum and ileum, while other parts of the gastrointestinal tube (duodenum, colon or stomach) may be affected, although exclusively rare. It is presented as chronic gastrointestinal disease leading to malnutrition syndrome. Conditions of long-lasting coeliac disease which become resistant to conventional treatment are hallmarks for type 1 EATL. The constitutional lymphoma symptoms may be a part of the disease presentation but later in the advanced stage. Suboclusion or bole perforation causing peritonitis may be the first signs of lymphoma leading to misdiagnosis. Diagnosis should rely on excisional biopsy or if operated on the operative material. The most common macroscopic picture is the occurrence of multiple ulcerating raised mucosal masses or one or more ulcers, or large exophytic mass (2). EATL is an intestinal tumor of intraepithelial $\mathrm{T}$ lymphocytes showing varying degrees of transformation but mostly with the prevalence of large T-cell immersed in inflammatory reactive background. If the tumor shows monomorphic medium-sized cells, it is MEITL, formerly type II EATL. Based on the current molecular analysis, there is an overgrowing data that delineates 2 types of EATL. Type I EATL has been characterized by TCR mutation in the $\alpha \beta$ chain region with typical immune profile: CD3+, CD4-, CD8-/+, CD56-, HLA-DQ2/-DQ8 and recently identified strong nuclear expression of megakaryocyteassociated thyrosine kinase (MATK) (37). This type is strongly related to the coexisting celiac disease. MEITL presumably originates from cytotoxic T-cells or NK-cells. Immunoprofile is distinctive: CD3+, CD4-, CD8+, CD56+, with the rearrangement mostly in the $\gamma \delta$ chain of TCR, with the $36 \%$ of STAT5B mutations and recurrent SETD2 alterations, as the most recent findings $(2,38)$. The aforesaid type is not casually related to the preexisting celiac disease.

HSTCL is one of the rarest PTCL entities determined by high aggressive nature and very poor outcome even with a highly aggressive treatment 
approach (4). It most frequently occurs in younger or middle-aged males in the setting of immunosuppressive treatment for chronic autoimmune disease $(39,40)$. The basic clinical finding is characterized by the primary spleen and hepatic enlargement with bone marrow infiltration resulting in marrow failure in over $2 / 3$ of cases. Lymph node involvement is uncommon at presentation. The disease starts suddenly with prominent B symptoms (malaise, high body temperature, and general breakdown), pancytopenia (mostly severe thrombocytopenia and anemia) resembling acute leukemia. The diagnosis should rely on liver, spleen or bone marrow biopsy or diagnostic splenectomy if necessary. Hepatic biopsy reveals sinus infiltration with atypical monotonous lymphoid cells with medium-sized nuclei. Large cell or blastic features may be found in advanced proliferation. Bone marrow biopsy reveals diffuse intrasinusoidal infiltration progressing toward peripheral blood involvement. In spleen biopsies, red pulp infiltration accompanied with white pulp atrophy is the major finding. The HSTCL immune profile is CD3+, CD56+/-, CD4-, CD8-/+, CD5-, EBV-, while $\gamma \delta$ TCR rearrangement can be determined only by molecular techniques (FISH, RT-PCR). The genetic profile reveals isochromosome 7 as a consistent finding, while in disease progression other numerical or structural chromosomal abnormalities have been described (2). The presumed cell of origin is $\gamma \delta$ cytotoxic T-cell of the innate immune system, very rare of $\alpha \beta$ type.

\section{CURRENT STANDARD OF CARE FOR SPECIFIC PTCL ENTITIES}

\section{General consideration}

Optimal management remains insufficiently defined for the majority of the PTCL entities given the fact they are rare and extremely diverse cancers. Clinical data for traditionally grounded $\mathrm{CHOP}$ (Cyclophosphamide, Doxorubicin, Vincristine, Prednisone) in the treatment of aggressive B-NHL has been extrapolated as a treatment paradigm for PTCL, occupying central position as the backbone in upfront setting for a long period of time. Unfortunately, results were remarkably worse than that of patients with aggressive B-NHL with the much lower overall response rate (ORR), while overall survival
(OS) remained unacceptably poor. In general, metaanalysis of the phase II studies on CHOP/CHOP-like regimens in PTCL showed pooled 5-OS ranging from $20 \%$ for EATL to $57 \%$ for ALCL (41). The introduction of Etoposide to CHOP (CHOEP) was a next step forward which significantly improved ORR and progression-free survival (PFS), but without obvious extension in OS. Some of the extranodal entities (i.e. ENKTCL and EATL) do not respond to CHOP/ CHOEP which led to redirection of upfront management to L-Asparaginase (L-Aspa)-based regimens or other non anthra-cycline-based regimens. L-Aspa significantly improved ORR, PFS and even OS in ENKTCL and became a new golden standard in upfront management. Brentuximab vedotin (BV) is the first biological agent which made tremendous improvement in relapse setting, paving its path to the upfront management of CD30+ PTCL. Providing sustained remission remains a cardinal clinical problem in PTCL. Upfront induction regimens are insufficient in achieving durable remission, except perhaps in the early stage of ALCL, ALK+. Regarding unfavorable post-induction clinical course, all achieved remissions need to be consolidated with auto-SCT immediately after induction in order to extend PFS and OS. Current clinical guidelines recommend such a scenario as the gold standard in all transplant eligible patients with regard to longer remission duration, while cure remains questionable. Allo-SCT seems to be powerful enough to improve OS significantly. No data outside clinical trials support the use of upfront allo-SCT consolidation, except perhaps in HSTCL given the fact that autoSCT is suboptimal $(4,5)$. Secondary allo-SCT may be considered whenever possible and available in relapsed/refractory setting. In general, R/R PTCL has no evidence-based management and has extremely poor outcome. New agents are warranted.

Some of the most important traditionally welldefined prognostic parameters in B-NHL remain also important in PTCL. For instance, the International Prognostic Index (IPI) is one of the most useful tools in PTCL as well (4). Male sex has been defined as an adverse prognostic factor for PTCL. The EBV-DNA copy number correlates with a tumor load and is an adverse outcome predictor in ENKTCL, specifically. All of the aforesaid clinical tools should be incorporated in treatment decision making. 


\section{Management (upfront and relapse setting) for nodal entities (PTCL-NOS, AITL, ALCL ALK+ and ALK-)}

Given the fact that primary nodal PTCL are the most common, the majority of randomized trials have been conducted it this setting. The abovementioned $\mathrm{CHOP} / \mathrm{CHOP}-$ like regimens have been widely used for the treatment of nodal PTCL, but with disappointing overall results. Based on the data published by the Swedish Lymphoma Registry and retrospective ad-hoc analysis by the German HighGrade NHL Study Group, incorporation of etoposide to $\mathrm{CHOP}$ (i.e. CHOEP) in younger patients $(\leq 60$ years) has demonstrated some benefit, mostly regarding event-free survival (EFS) but not OS $(41,42)$. CHOEP or CHOP has become a standard treatment modality for nodal subtypes but is not curative in most of the patients. Primary refractory and chemotherapy resistant disease occurs in around 33\% of patients treated with $\mathrm{CHOP}$ or CHOEP, which is strongly associated with dismal outcome (43). It appears that upfront reinforcement is warranted for the better disease control or achieving long-standing remission. Single chemotherapy treatment itself without high-dose (HD) therapy accompanied with auto-SCT is not sufficient for long-standing remission since relapse is almost inevitable. The use of "dose-dense" CHOEP in bi-weekly schedule (i.e. CHOEP-14) in 6 consecutive cycles with HD consolidation of first remission followed by autoSCT became a golden standard for nodal entities. This type of management has demonstrated ORR and CR, $82 \%$ and $51 \%$, respectively (44). At median follow-up of 4.5 years all of the 3 included nodal entities had an estimated 5-OS and PFS of $47 \%$ and $38 \%$ (PTCL-NOS), $52 \%$ and $49 \%$ (AITL), $70 \%$ and 61\% (ALCL, ALK-), respectively (44). In this sense, upfront induction therapy should be accompanied with HD therapy with auto-SCT support as a consolidation of first major response (CR or PR) in all chemo-sensitive and transplant eligible patients (4). The aforesaid management offers long-term survival in about half of the treated patients (45). However, this dose-intensified approach is not applicable in large number of patients. Therefore, inclusion in a clinical trial is recommended whenever possible.

Regarding clinical success in the treatment of some aggressive B-NHL, the "old-new" regimen DA-EPOCH ("dose-adjusted" Etoposide,
Prednisone, Vincristine, Cyclophosphamide and Doxorubicin) (46), has been studied in PTCL as induction setting. A multicenter phase II study was conducted in 42 patients with nodal subtypes (PTCL-NOS 21, AITL 17, ALCL, ALK+ 2 and ALCL, ALK- 1). The obtained results demonstrated high ORR and CR rates, and 2-year PFS and OS, 78\%, $61 \%, 53.3 \%$ and $73.2 \%$, respectively. Patients aged $\leq$ 60 years had even better responses and survival rates (ORR 94.1\%, CR 70.6\%, PFS $62.5 \%$ and OS $82.4 \%$ ). The regimen was well tolerated with acceptable toxicity profile even in elderly indicating it as a reasonable option in induction setting for nodal type PTCL which may improve the outcome (47). However, this needs confirmation in a larger phase III trial before adopting it as a standard.

Front line Hyper-CVAD/MA (hyper-fractioned Cyclophosphamide, Vincristine, Doxorubicin, HD Dexamethasone/ HD Methotrexate and HD Cytarabine) has been studied along with other regimens in retrospective study in 341 patients (only $6 \%$ received this regimen). It was found that it has produced high ORR of $85 \%$ with CR of $80 \%$, which was quite better than standard CHOP. However, no significant difference has been observed in 3-OS (CHOP-like 55\% vs. HyperCVAD 49\%) (48).

Single agent gemcitabine showed activity against lymphoma (49). A phase II prospective study has been testing PEGS regimen (Cisplatin, Etoposide, Gemcitabine, and Methylprednisolon) in upfront setting, however, with the disappointing overall results (ORR 39\%, and 2-PFS 14\%) (50). Another prospective randomized study has been conducted exploring the front line GDPT (Gemcitabine, Cisplatin, Prednisone, Thalidomide) regimen vs. CHOP, in 103 patients with PTCL. Patients were randomly allocated to equal groups. Statistic significant difference has been found between two compared therapies in terms of ORR, 2PFS, $2-\mathrm{OS} 52 \%$ vs. $33 \%, 57 \%$ vs. $35 \%$, $71 \%$ vs. $50 \%$, respectively (51).

Upfront management with anti CD30 agent has been explored in the ESCHELON II trial. It was a phase III double-blind, placebo-controlled, randomized, active-comparator study of $\mathrm{A}+\mathrm{CHP}$ (Brentuximab vedotin $1.8 \mathrm{mg} / \mathrm{kg}+$ standard schedule Cyclophosphamide, Doxorubicin, Prednisone) vs. CHOP. It included 452 patients with previously untreated PTCL (75\% with systemic ALCL). Patients were randomly assigned 1:1 to receive either $\mathrm{CHOP}$ or $\mathrm{A}+\mathrm{CHP}$ for 6-8 cycles in 21-day cycles. Results 
have demonstrated significant superiority of $\mathrm{A}+\mathrm{CHP}$ vs. CHOP in terms of PFS, 48.2 vs. 20 months, p 0.01 . OS was also improved in $\mathrm{A}+\mathrm{CHP}$ group with manageable safety profile (52). This study gave a new insight in close future eventual recomposition of upfront management for CD30+ PTCL. There are few published trials which compared frontline $\mathrm{CHOP}$ therapy vs. CHOP with the addition of some of the novel compounds (i.e. pralatrexate, romidepsin, or others). In this sense, a phase II study of COEP+P (Cyclophosphamide, Vincristine, Etoposide, Prednisone + Pralatrexate) vs. $\mathrm{CHOP}$ has been conducted in 33 PTCL patients. However, the final results did not show any improvement of novel therapy compared to historical data using $\mathrm{CHOP}$ (53).The same results were obtained for the phase II study of CHOP vs. CHOP + bortezomib with no difference in terms of PFS and OS (54). A phase III study of romidepsin + $\mathrm{CHOP}$ vs. $\mathrm{CHOP}$ is still underway.

In this section, BIA-ALCL should be mentioned as novel defined entity with its specific treatment recommendations. When the disease is localized to the capsule, the surgical goal is capsulectomy and removal of a breast implant. If a suspected lymph node is present, excisional biopsy is needed. Contralateral implant removal may be considered, due to the possibility of lymphoma in the contralateral breast (4.6\%) (10). In patients with residual disease, unresectable or with positive margins radiotherapy may be used. In extended disease with positive lymph nodes, there is limited data but it is certain that systemic therapy is needed. Therapeutic approaches may include anthracyclinebased regimens, BV, or involvement in clinical trials if possible.

Relapse after frontline induction therapy is an inevitable event in very high percentage of patients. The most susceptible entity for relapse remains PTCL-NOS, while ALCL, ALK+ has the highest chance of long remission or cure. Early relapse or primary refractoriness is associated with catastrophic outcome. Therefore, the choice of proper treatment modality remains a central target point in therapeutic decision making. At this time point, the only globally approved targeted agent in R/R PTCL is an anti-CD30 immunoconjugate $\mathrm{BV}$ in CD30+ ALCL. This data has been observed from a phase II pivotal trial in heavily pretreated patients with systemic ALCL with an ORR of $86 \%$ and a CR rate of $57 \%$ with a median response duration of 12.6 months
(55). BV may be a useful tool to bridge eligible patients toward allo-SCT. Exclusively, CD30+ PTCL-NOS may be a part of BV treatment in R/R setting. Other nodal entities such as AITL, and PTCL-NOS CD30- has no evidence-based recommendation in a relapsed setting. Entering clinical trial is of absolute benefit.

Outside clinical trials, in the absence of defined treatment, salvage regimens on the basis of extrapolation from B-NHL may be recommended. In this sense, fit and younger patients may be salvaged with ICE (Ifosfamide, Carboplatin, Etoposide) or DHAP (HD Dexamthason, Cisplatin, Etoposide, HD Cytarbine) prior preceding to allo-SCT as a potentially curative option. This scenario is accompanied with severe adverse events regarding overtreatment but feasible in some portion of patients. For unfit and frail patients, single agent chemotherapy in a palliative manner may be recommended. Active agents in this setting are gemcitabine and bendamustine with an ORR $50 \%$, well-tolerated but with moderate duration of response (DOR) $(56,57)$.

The role of allo-SCT has been investigated in limited series, mostly by retrospective observation in relapsed or refractory setting (58-61). This modality is feasible in limited proportion of younger and fit patients resulting in prolonged survival mostly based on GvL effect and immunologic maintenance. In order to improve response, donor lymphocyte infusion (DLI) may be added. Potentially possible post allo-SCT relapses may be offered secondary alloSCT or perhaps haploidentical SCT, but there is no evidence-based data supporting such a scenario.

\section{Management (upfront and relapse setting) for extranodal entities (ENKTCL, EATL, HSTCL)}

ENKTCL is one of the extranodal entities which significantly differ in terms of prognosis and outcome based on Ann Arbor clinical stage of the disease. Considering this fact, two categories of patients have been identified: stage I/II vs. stage III/IV. Basic systemic treatment for ENKTCL is unique in the context of PTCL being permanently diverted to $\mathrm{L}-\mathrm{Aspa}$ based induction regimens. This is primarily because of the documented L-Aspa superiority over anthracycline-based regimens which are inefficient in long-term disease control (62-66). 
Two-thirds of patients belong to stage I/II disease. In stage $\mathrm{I} / \mathrm{II}$, concomitant radiotherapy with chemotherapy or sequential chemotherapy followed by chemoradiation are the backbones of management. In stage I diseases, early radiotherapy yield maximum benefit both in terms of PFS and OS. It has been defined that radiation doses should overcome 50 Gy particularly if it is a single treatment modality. In a concurrent approach, Cisplatin is a radiosensitizer with the most common use preferentially in a weekly schedule, while radiotherapeutic doses may be reduced to 40-45 Gy. In fit and young patients, SMILE (L-Aspa, Dexamethason, Cytarabine, HD MTX, Etoposide) regimen 2 cycles followed by concurrent chemoradiation is optimally recommended.

Stage III/IV ENKTCL is an advanced disease with a dismal outcome since all known modalities seem to be suboptimal. SMILE regimen in fit and young patients offers the highest response rates. All sensitive patients should be consolidated with autoSCT if treated with curative intent. Elderly and frail patients may benefit from dose-modified SMILE, LAspa+Dex+Mtx or single L-Aspa induction in palliative manner (67). Allo-SCT in first remission may be an option but not beyond clinical trials.

Relapsed/refractory ENKTCL is almost inevitably fatal. No randomized phase III data exist on therapeutic management in this setting. Treatment is guided by single-center choice relying on data obtained from anecdotal case reports or small cohorts of patients. Before making a decision whether the treatment is required, it is strongly recommended to perform a biopsy in all PET/CT positive lesions due to high frequency of inflammatory changes secondary to ulceration (4). The treatment modality should be tailored depending on the duration of primary remission. In early relapse (< 12 months), non cross-resistant chemotherapy which has not been used in upfront setting seems to be a reasonable option. In this sense, L-Aspa regimens may be used if they have not been previously applied or as a salvage with gemcitabine-based regimens e.g. GELOX (Gemcitabine, L-Aspa, Oxaliplatine) (68), if L-Aspa has been used. Although data considering allo-SCT in relapsed/ refractory settings are missing through evidencebased randomized trials, it seems an acceptable option in transplant-eligible patients who have a sensitive relapse. There have been reports of seven patients treated with pembrolizumab in a setting of
L-Aspa failure reaching significant response (69). It has been recognized that high PD-L1 expression is directed through high LMP1 overexpression in cancer cells of ENKTCL due to its unique oncogene driving mechanism depending on EBV infection. A case report of an anti-CD38 monoclonal agent daratumumab has been published, indicating its significant activity in relapsed/refractory disease (70). Anti CD30 agent BV has also been reported to yield response in two cases of non-nasal ENKTCL. However, both patients had limited response duration $(71,72)$. A combination of PD1 inhibitor pembrolizumab with BV may be a future targeted therapy in relapsed/refractory setting. Data are expecting from ongoing trials.

EATL and MEITL are very rare neoplasms with no prospective randomized series. Almost half of the patients are inadequate for optimal management because of poor performance status, infection, malnutrition or advanced age. Most of the studies published point to very disappointing outcomes in both types of diseases, with the average $5-$ OS in less than $20 \%$ even in the series encompassing aggressive multimodality treatment (surgical resection, chemotherapy, and auto-SCT). It has been recognized that malnutrition in longstanding celiac disease has a major impact on survival in type I EATL (73). One of the larger cohort studies which included 61 patients in a median follow-up of 26 months showed that the aggressive multimodality treatment represents the most beneficial approach. However, even if the relapse rate were lowest compared to single treatment, 5-OS remained poor. The study pointed out that only 33\% of patients treated with a multimodal approach remained alive for 5 years compared to the group without auto-SCT where 5-OS was 14\% (74). It has been documented that dose-dense schedule CHOEP14 with auto-SCT has shown improved outcomes compared with standard CHOP (44). Nevertheless, anthracycline-based induction is not a treatment that offers any long-term disease control. In this sense, upfront treatment may be improved by the introduction of non antracycline-based therapies such as IVE/MTX (Ifosfamide, Vincristine, Etoposide, and Methotrexate) followed by auto-SCT as a modality with promising results, with 5-OS and PFS of $60 \%$ and $52 \%$, respectively (75). A single case report of the combination of pegylated (PEG LAspa) along with EPOCH regimen in a MEITL patient aged 70 years has been published. PEG L- 
Aspa was added at the $5^{\text {th }}$ cycle of chemotherapy and improved major response to treatment. The patient remained in remission over a one-year period before succumbing to relapsed disease (76). It is important to point out that multimodal treatment gives the opportunity for better disease control giving a chance for longer remission duration. Unfortunately, only half of the patient population with EATL/MEITL are aged $<70$ years and may undergo aggressive multimodal treatment recommended by actual guidelines.

In relapsed/refractory setting, no evidencebased specific treatment can be recommended. Based on the available guidelines, treatment should be diverted as for nodal entities. In case of a sensitive relapse consolidation with auto-SCT should be performed if it was not done previously. If a patient has already been consolidated with auto-SCT, then allo-SCT should be applied, if applicable. However, such a clinical scenario has not been documented in real world practice.

HSTCL is one of the extranodal T-cell lymphoma with the most aggressive and highly lethal clinical course. Considering its very low prevalence, no randomized data exist about the NCCN guidelines support study entrance to all patients with HSTCL, if available. If not, then it favors ICE induction regimen over anthracycline-based counterparts with immediate proceeding to allo-SCT in first remission in all responding and transplanteligible patients. Absolute benefit from allo-SCT has been observed in a term of immunologic maintenance - through GvL effect.

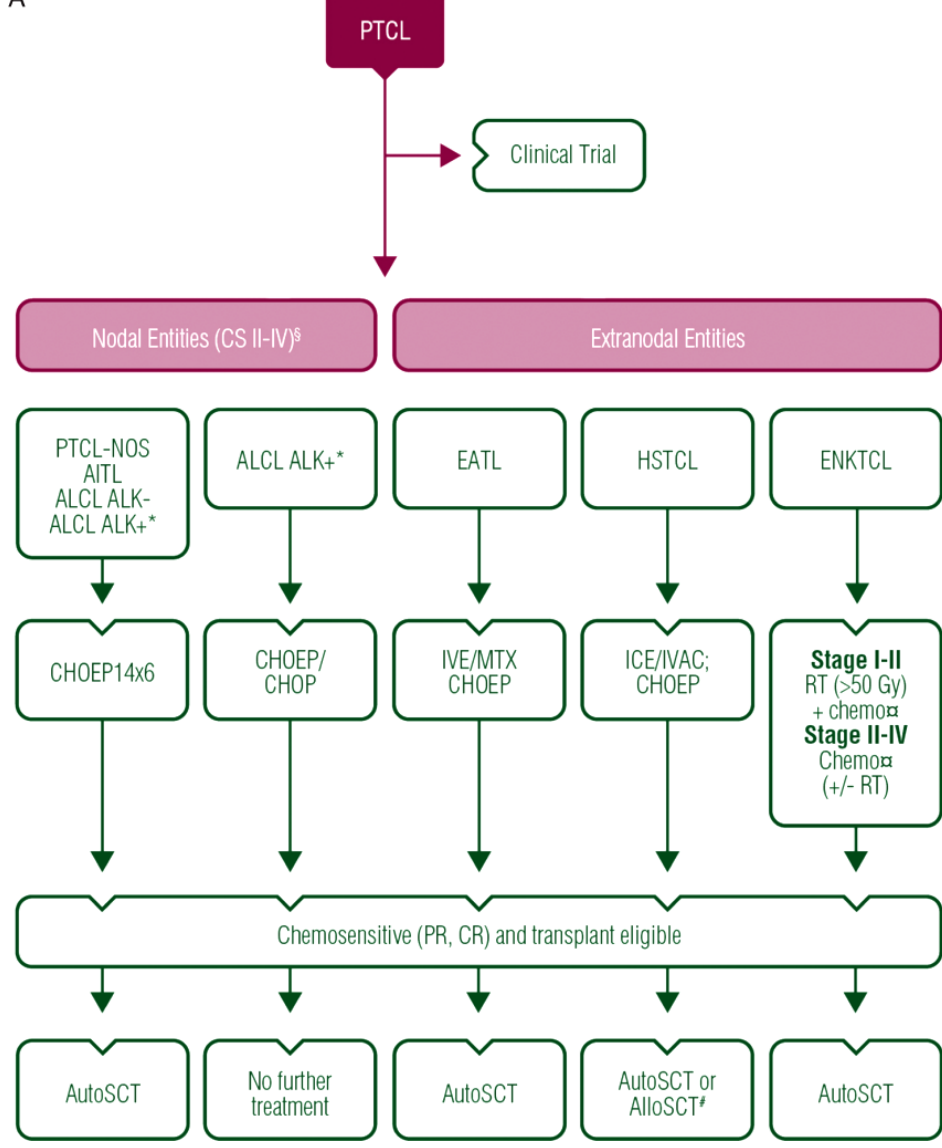

B

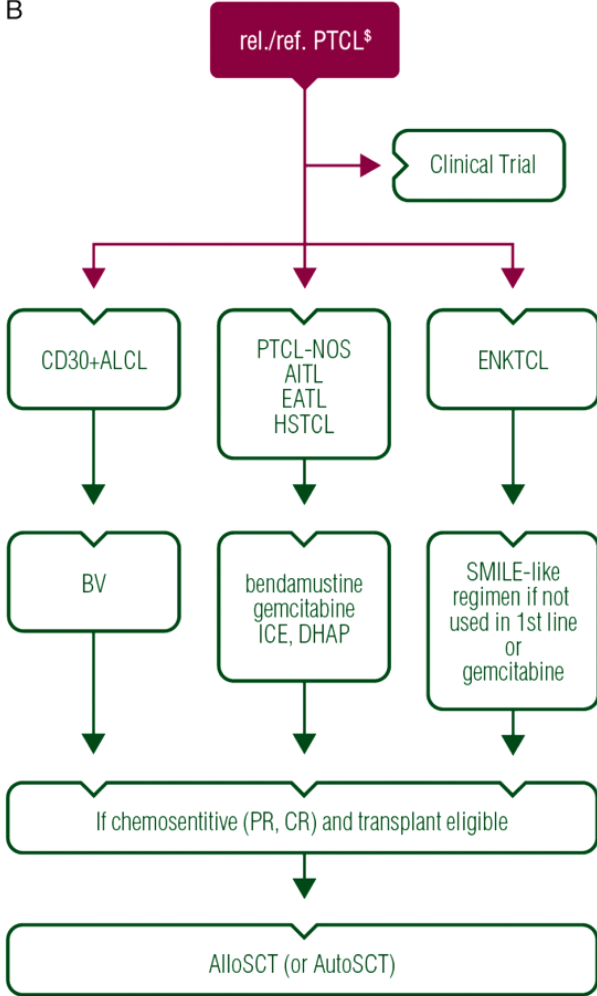

Figure 1. ESMO guidelines recommendation of the current management in upfront and $R / R$ setting of nodal and extranodal PTCL 
There is no evidence-based specific management of relapsed/refractory disease. Given the available guidelines, salvage treatments should be tailored upon duration of previous remission and other clinical relevant data offering re-challenge or introduction of the regimen that has non crossresistance with the previous one. Anecdotal sensitive cases should undergo allo-SCT if previously have been consolidated with auto-SCT. Entering clinical trial is strongly recommended. There is no evidencebased specific management of relapsed/refractory disease.

Summarized version of the latest treatment recommendations in upfront and $R / R$ setting by ESMO are shown in Figure 1.

\section{Most current trials in R/R PTCL}

A significant number of new compounds entered early phase II trials offering a median response of $\sim 30 \%$ in $\mathrm{R} / \mathrm{R}$ setting as a single agent. Some of the drugs have been approved by the Federal Drug Agency (FDA) based on their preliminary response rates. In the EU, the European Medicine Agency (EMA) has rejected the approval of pralatrexate and romidepsin because of a lack of evidence for clear clinical benefit, although it gave orphan-drug designation for belinostat. Nevertheless, the obtained early results seem encouraging and have affected prompt creation of double-agent combination studies that improved ORR even more. Studies are ongoing and larger cohorts are awaited which will give us more affirmative answers in the future. We will discuss them in a short overview. All single and double novel agent trials are summarized in Tables 3 and 4, respectively.

Pralatrexate, a novel antifolate agent, has been tested in R/R PTCL. The phase II study enrolled 115 patients (109 evaluable). All patients received a median of three therapies prior to study entry. Patients received $30 \mathrm{mg} / \mathrm{m}^{2}$ of pralatrexate per week for 6 weeks in 7-week cycles until disease progression or the development of unacceptable toxicity. The ORR was $29 \%$ (CR $11 \%$, and PR 18\%), median DOR was 10.1 months with PFS and OS, 3.5 and 14.5, respectively. The drug received FDA approval (78).

The aurora kinases are serine/threonine kinases included in mitotic spindle activity and other mitotic events in the cell cycle. Three isoforms have been identified, so far (A, B and C) with alisertib to be the first in the class of aurora $A$ kinase (AAK) inhibitors. PTCL cancers are marked with high expression of the aurora kinases which are significantly related to cancer proliferation. Very early phase I studies have demonstrated AAK inhibitors activity in R/R PTCL (79). Alisertib, an oral AAK inhibitor which has been evaluated in two phases II

Table 3. Novel single-agent trials in R/R PTCL

\begin{tabular}{c|c|c|c|c|c|c|c|c}
\hline \hline Single-agent & $\begin{array}{c}\text { No } \\
\text { patients }\end{array}$ & $\begin{array}{c}\text { Study } \\
\text { phase }\end{array}$ & $\begin{array}{c}\text { ORR/CR } \\
\mathbf{\%}\end{array}$ & $\begin{array}{c}\text { DOR } \\
\text { months }\end{array}$ & $\begin{array}{c}\text { EFS } \\
\text { months }\end{array}$ & $\begin{array}{c}\text { PFS } \\
\text { months }\end{array}$ & $\begin{array}{c}\text { OS } \\
\text { months }\end{array}$ & ref \\
\hline Pralatrexate & 109 & II & $29 / 11$ & 10.1 & 3.5 & 3.5 & 14.5 & 78 \\
\hline Alisertib & 37 & I/II & $30 /-$ & 3 & & 3 & 4 & 80 \\
\hline Romidepsin & 130 & II & $25 / 15$ & $28 / \mathrm{nr}^{\circ}$ & - & & & 83 \\
\hline Belinostat & 120 & II & $25.8 / 13$ & 13.6 & - & 1.6 & 7.9 & 85 \\
\hline Crizotinib & 9 & II & $100 / 100$ & - & - & 63.7 & 72.7 & $86 / 7$ \\
\hline Duvelisib & 16 & I & $50 / 19$ & & & & & 88 \\
\hline Tenalisib & 5 & I & $40 /-$ & & & & & 89 \\
\hline Azacytidine & $19 / 14^{*}$ & II & $53 / 26$ & - & - & - & - & 90 \\
\hline Tipifarnib & 18 & II & $-/ 14$ & & & & & 92 \\
\hline Mogamulizumab & 37 & II & $35 / 14$ & - & - & 3 & - & 93 \\
\hline Nivolumab & 5 & I & $40 /-$ & 11.5 & & & & 95 \\
\hline \hline
\end{tabular}

* patients with AITL, ${ }^{\circ}$ nr-not reached for CR patients 
Table 4. Novel double or triple-agent combination trials in $R / R P T C L$

\begin{tabular}{c|c|c|c|c|c}
\hline \hline Combination of agencies & No & Type of the diseases & $\begin{array}{c}\text { ORR/CR } \\
\%\end{array}$ & $\begin{array}{c}\text { DOR } \\
\text { months }\end{array}$ & ref \\
\hline Romidepsin + pralatrexate & 13 & BCL/TCL & $77 / 33$ & - & 96 \\
\hline Romidepsin + lenalidomide & 10 & BCL/TCL/myeloma & $50 /-$ & 31 & 97 \\
\hline Romidepsin + bortezomib & 2 & CLL/BCL/TCL & $0 / 0$ & - & 98 \\
\hline Romidepsin + alisertib & 3 & BCL/PTCL & $-/ 33$ & - & 100 \\
\hline Romidepsin + duvelisib & 11 & PTCL & $64 / 36$ & - & 101 \\
\hline Romidepsin + lenalidomide + carfilzomib & 16 & TCL & $31 / 38.7$ & 38.7 & 99 \\
\hline Duvelisib + bortezomib & 10 & PTCL & $50 / 30$ & - & 101 \\
\hline \hline
\end{tabular}

studies (dose range $50 \mathrm{mg}$ ) demonstrated an ORR of $\sim 30 \%$, the median DOR was 3 months with the median PFS and OS of 3 and 8 months, respectively $(80,81)$. A combination of the AAK inhibitors with PD1/PDL-1 inhibitors and phosphatidyl-inositol-3 kinases (PI3K) may be an active schedule in the future, as preclinical models have demonstrated (82).

Histone deacetylase (HDAC) inhibitors are epigenetic modifiers with the defined single agent activity in R/R PTCL. Randomized studies have been conducted for romidepsin, vorinostat, and belinostat in CTCL, as well as systemic forms of PTCL with satisfactory therapeutic profile, leading to FDA approval of these agencies in $R / R$ setting. Romidepsin is a unique, first in class, selective, bicyclic HDAC inhibitor with potent activity against PTCL. In pivotal phase II trial of Shustov A, et al. which enrolled 130 patients with R/R PTCL (PTCL-NOS, AITL, and ALCL, ALK-) who received a median of $\geq 1$ prior therapy high activity of a single agent romidepsin has been documented (83). The dose schedule for romidepsin was $14 \mathrm{mg} / \mathrm{m}^{2}$ as 4-hour infusion on days 1,8 , and 15 every 28 days. The study showed objective ORR of $25 \% \quad(15 \%$ with $\mathrm{CR} / \mathrm{CR}$ unconfirmed). Median DOR was 28 months and was not reached for those who achieved CR/ Cru. This study was conducted in younger and elderly demonstrating no differences in effect and safety profile. It has been established that PTCL cancers are uniquely sensitive to epigenetic modifiers. In this sense, a phase I study has been conducted with 5azacytidine (5-AZA) and romidepsin (both epigenetic modifiers) which demonstrated higher activity in T-cell NHL over B-cell NHL (84). Belinostat is a hydroxamic acid-derivative panHDAC inhibitor that broadly inhibits all zincdependent enzymes. It has been evaluated in the phase II study in patients with R/R PTCL who received at least one prior therapy. The dose schedule of belinostat was $1000 \mathrm{mg} / \mathrm{m}^{2}$ on days 1-5 in 21-day cycles. A total of 129 patients were enrolled (120 evaluable) with the ORR of $25.8 \%$ (13\% CR and $18 \%$ PR). The median DOR was 13.6 months, median PFS and OS were 1.6 and 7.9 months, respectively. The monotherapy with belinostat is active and produced a durable response with a manageable toxicity profile (85). Vorinostat has been approved for CTCL.

Crizotinib is an ALK/ROS1 inhibitor with dramatic activity in ALK+ R/R PTCL, particularly ALCL, ALK+. Although this type of PTCL has a favorable outcome, it carries ominous prognosis in relapsed/ refractory disease. Crizotinib was tested in phase II study in 11 patients with ALK+ R/R PTCL (9 ALCL) in a dose range $250 \mathrm{mg}$ twice daily. All patients with ALK+ ALCL achieved CR with 2-PFS and OS of 63.7, and 72.7, respectively. One patient had remission which lasted $>30$ months under continuous administration of crizotinib (86). There has been a single report of $C R$ in a patient with ALK+ ENKTCL who had chemorefractory disease in progression after two prior therapies. The patient was successfully salvaged with crizotinib reaching metabolically $C R$ which lasts during regular oneyear follow-up period (87). The remission duration and the duration of remission maintenance therapy with crizotinib needs further evaluation.

Duvelisib is an oral PI3K $\delta / \gamma$ dual inhibitor that has been tested in phase I, open-label trial for hematological malignancies in 210 patients of which 16 patients with R/R PTCL. It was administered as 8$100 \mathrm{mg}$ twice daily in a dose escalation schedule. The ORR was $50 \%$ with 3 CR recorded for PTCL (88). Tenalisib is a next generation highly specific PI3K $\delta / \gamma$ inhibitor tested in phase $\mathrm{I} / \mathrm{Ib}$ in patients with 
CTCL and R/R PTCL, which resulted in ORR $50 \%$. The study is ongoing, preliminary results are encouraging with the acceptable safety profile (89).

5-AZA has been explored in the R/R PTCL subtype with 19 patients included (14 with AITL). It was administered as a subcutaneous injection of 75 $\mathrm{mg} / \mathrm{m}^{2}$. The ORR was $53 \%$, markedly higher in the AITL subgroup of patients. It was found that TET2 mutation was predictive for response which was durable in most of AITL patients (90).

Forodesine has been evaluated in phase I/II study which was discontinued in the EU and USA, but the study has been completed in Japan where it has been registered for R/R PTCL. The ORR was $24 \%$ (10 of 41 with 4 CR) (91).

Tipifarnib is an oral farnesyl-transferase inhibitor tested in a phase II trial of 18 patients who received tipifarnib $600 \mathrm{mg}$ twice daily on days $1-7$ and 15-21 in 28-day cycle. It demonstrated 17 PR at the cost of high grade neutropenia and thrombocytopenia (92).

Mogamulizumab, a defucolysated humanized anti-CCR4 antibody, has been studied in CCR4+ R/R PTCL and CTCL. A phase II study was conducted with 37 patients included. With a dosing schedule of $1 \mathrm{mg} / \mathrm{kg}$ per week in 8 weeks, the ORR was 35\% (CR $14 \%)$ with a median PFS of three months. High grade lymphocytopenia occurred in $73 \%$ of patients (93).
The drug is found to be remarkably active in ATLL entity.

Anti CD52 monoclonal antibody alemtuzumab has been evaluated in R/R PTCL either as a single agent or as combination therapy with the ORR ranging from $36 \%$ to $54 \%$. However, severe opportunistic infections limited its further inclusion as a therapeutic agent (94).

Immune-checkpoint inhibitor nivolumab has been tested in early phase II study for R/R B/T-NHL. The study included 81 patients ( 23 with R/R PTCL) with $1-3 \mathrm{mg} / \mathrm{kg}$ dose every two weeks. Among five evaluable patients, two PRs were achieved with sustained DOR (95). Several other immune-check inhibitor trials are ongoing incorporating pembrolizumab, durvalumab, and avelumab.

As for the combined studies that have embedded two new compounds, phase I/II trials have been conducted offering significantly higher responses ranging for $\geq 50 \%$. The abovementioned trials combined mostly HDAC inhibitor romidepsin with pralatrexate, lenalidomide, bortezomib, alisertib, duvelisib. There has been a trial published exploring triple combinations of romidepsin, lenalidomide, and bortezomib. Early results seem promising. Nevertheless, the larger cohorts are awaited for more objective discussion (96-101). 


\section{References}

1. Vose J, Armitage J, Weisenburger D. International peripheral T-cell and natural killer cell/T-cell lymphoma study: pathology findings and clinical outcomes. J Clin Oncol 2008; 26 (25):4124-30. https://doi.org/10.1200//CO.2008.16.4558

2. Swerdlow SH, Campo E, Harris NL, et al. WHO Classification of Tumours of Haemotopoietic and Lymphoid Tissues. 4th ed. Geneva, Switzerland: World Health Organization; 2008.

3. Swerdlow SH, Campo E, Peleri SA, et al. The 2016 revision of the World Health Organization classification of lymphoid neoplasms. Blood 2016; 127 (20): 2375-90.

https://doi.org/10.1182/blood-2016-01-643569

4. d'Amore F, Gaulard P, Trümper $\mathrm{L}$, et al. Peripheral T-cell lymphomas: ESMO clinical practice guidelines for diagnosis, treatment and follow-up. Ann Oncol 2015; 26 suppl 26: 108-115. https://doi.org/10.1093/annonc/mdv201

5. Horwitz SM, Ansell SM, Ai WZ, et al. NCCN Guidelines Insights: T-cell lymphomas. Version 2.2018. J Natl Compr Canc Netw 2018; 16 (2): 12335.

https://doi.org/10.6004/jnccn.2018.0007

6. Biggar RJ, Engels EA, Frish M, et al. Risk of T-cell lymphoma in persons with AIDS. J Acquir Immune Defic Syndr 2000; 26 (4): 371-6. https://doi.org/10.1097/00126334-200104010-00015

7. de Jong D, Vasmel WL, de Boer JP, et al. Anaplastic large-cell lymphoma in women with breast implants. JAMA 2008; 300 (17): 2030-5. https://doi.org/10.1001/jama.2008.585

8. Gaulard P, de Leval L. Pathology of peripheral Tcell lymphomas: where do we stand? Semin Hematol 2014; 51 (1): 5-16.

https://doi.org/10.1053/j.seminhematol.2013.11.003

9. Asano N, Suzuki R, Kagami Y, et al.
Clinicopathologic and prognostic significance of cytotoxic molecule expression in nodal peripheral T-cell lymphoma, unspecified. Am J Surg Pathol 2005; 29 (10): 1284-93.

https://doi.org/10.1097/01.pas.0000173238.17331.6b

10. Swerdlow SH, Jaffe ES, Brousset $P$, et al; International Lymphoma Study Group. Cytotoxic T-cell and NK-cell lymphomas: current questions and controversies. Am J Surg Pathol 2014; 38(10):e60-e71.

https://doi.org/10.1097/PAS.0000000000000295

11. Perry AM, Warnke RA, Hu Q, et al. Indolent T-cell lymphoproliferative disease of the gastrointestinal tract. Blood 2013; 122(22):3599-606. https://doi.org/10.1182/blood-2013-07-512830

12. Petrella T, Maubec E, Cornillet-Lefebvre $\mathrm{P}$, et al. Indolent CD8-positive lymphoid proliferation of the ear: a distinct primary cutaneous T-cell lymphoma Am J Surg Pathol 2007; 31 (12): 188792.

https://doi.org/10.1097/PAS.0b013e318068b527

13. Sun JC, Lanier LL. NK cell development, homeostasis and function: parallels with CD8 T cells. Nat Rev Immunol 2011;11 (10): 645-57. https://doi.org/10.1038/nri3044

14. Lanier LL, Testi R, Bindl J, Phillips JH. Identity of Leu-19 (CD56) leukocyte differentiation antigen and neural cell adhesion molecule. J Exp Med 1989; 169 (6): 2233-8.

https://doi.org/10.1084/jem.169.6.2233

15. Chan JK, Tsang WY, Ng CS. Clarification of CD3 immunoreactivity in nasal $\mathrm{T} /$ natural killer cell lymphomas: the neoplastic cells are often CD3 epsilon+. Blood 1996; 87 (2): 839-41.

https://doi.org/10.1182/blood.V87.2.839.bloodjour $\underline{\text { nal872839 }}$

16. Felgar RE, Macon WR, Kinney MC, et al. TIA-1 expression in lymphoid neoplasms. Identification 
of subsets with cytotoxic T lymphocyte or natural killer cell differentiation. Am J Pathol 1997; 150 (6): 1893-900.

17. de Leval L, Rickman DS, Thielen C, et al. The gene expression profile of nodal peripheral T-cell lymphoma demonstrates a molecular link between angioimmunoblastic T-cell lymphoma (AITL) and follicular helper T (TFH) cells. Blood 2007; 109 (11): 4952-63.

https://doi.org/10.1182/blood-2006-10-055145

18. Iqbal J, Weisenburger DD, Greiner $\mathrm{TC}$, et al. Molecular signatures to improve diagnosis in peripheral T-cell lymphoma and prognostication in angioimmunoblastic T-cell lymphoma. Blood 2010; 115 (5): 1026-36.

https://doi.org/10.1182/blood-2009-06-227579

19. Cuadros M, Dave SS, Jaffe ES, et al. Identification of a proliferation signature related to survival in nodal peripheral T-cell lymphomas. J Clin Oncol 2007; 25(22): 3321-9.

https://doi.org/10.1200//CO.2006.09.4474

20. Dupuis J, Emile JF, Mouniar N, et al. Prognostic significance of Epstein-Barr virus in nodal peripheral T-cell lymphoma, unspecified: A Groupe d'Etude des Lymphomes de l' Adulte (GELA) study. Blood 2006; 108 (13): 4163-9.

https://doi.org/10.1182/blood-2006-04-017632

21. Went P, Agostinelli C, Gallamini A, et al. Marker expression in peripheral T-cell lymphoma: a proposed clinical-pathologic prognostic score. J Clin Oncol 2006; 24 (16): 2472-9.

https://doi.org/10.1200//CO.2005.03.6327

22. Iqbal J, Wright G, Wang C, et al. Gene expression signatures delineate biological and prognostic subgroups in peripheral T-cell lymphoma. Blood 2014; 123 (19): 2915-23.

https://doi.org/10.1182/blood-2013-11-536359

23. de Leval L, Gaulard P. Pathobiology and molecular profiling of peripheral T-cell lymphomas. Hematology Am Soc Hematol Educ Program 2008; 2008: 272-9.

https://doi.org/10.1182/asheducation-2008.1.272
24. Rodriguez-Pinilla SM, Atienza L, Murillo C, et al. Peripheral T-cell lymphoma with follicular T-cell markers. Am J Surg Pathol 2008; 32 (12): 1787-99. https://doi.org/10.1097/PAS.0b013e31817f123e

25. Dupuis J, Boye K, Martin N, et al. Expression of CXCL13 by neoplastic cells in angioimmunoblastic T-cell lymphoma (AITL): a new diagnostic marker providing evidence that AITL derives from follicular helper T cells. Am J Surg Pathol 2006; 30 (4): 490-4. https://doi.org/10.1097/00000478-200604000-00009

26. Grogg KL, Morice WG, Macon WR. Spectrum of bone marrow findings in patients with angioimmunoblastic T-cell lymphoma. $\mathrm{Br} \quad \mathrm{J}$ Haematol 2007; 137 (5): 416-22. https://doi.org/10.1111/j.1365-2141.2007.06577.x

27. Sakata-Yanagimoto M, Enami T,Yoshida K, et al. Somatic RHOA mutation in angioimmunoblastic T cell lymphoma.Nat Genet 2014; 46 (2): 171-5. https://doi.org/10.1038/ng.2872

28. Attygalle AD, Kyriakou C, Dupuis J, et al. Histologic evolution of angioimmunoblastic T-cell lymphoma in consecutive biopsies: clinical correlation and insights into natural history and disease progression. Am J Surg Pathol 2007; 31 (7): 1077-88. https://doi.org/10.1097/PAS.0b013e31802d68e9

29. Bayle C, Charpentier A, Duchayne E, et al. Leukaemic presentation of small cell variant anaplastic large cell lymphoma: report of four cases. Br J Haematol 1999; 104 (4): 680-8. https://doi.org/10.1046/j.1365-2141.1999.01238.x

30. Kinney MC, Collins RD, Greer JP, et al. A smallcell-predominant variant of primary Ki-1 (CD30) + T-cell lymphoma. Am J Surg Pathol 1993; 17 (9): 859-68.

https://doi.org/10.1097/00000478-199309000-00001

31. Castellar ERP, Jaffe ES, Said JW, et al. ALK-negative anaplastic large cell lymphoma is a genetically heterogeneous disease with widely disparate clinical outcomes. Blood 2014; 124 (9): 1473-80.

https://doi.org/10.1182/blood-2014-04-571091 
32. Clemens MW, Brody GS, Mahabir RC, Miranda RN. How to diagnose and treat breast implantassociated anaplastic large cell lymphoma. Plast Reconstr Surg 2018; 141 (4): 586e-99e.

\section{https://doi.org/10.1097/PRS.0000000000004262}

33. Loch-Wilkinson A, Beath K, Knight R, et al. Breast Implant-Associated Anaplastic Large Cell Lymphoma in Australia and New Zealand. Plastic Reconstr Surg 2017; 140 (4): 645-54. https://doi.org/10.1097/PRS.0000000000003654

34. Kim B, Roth C, Young V, et al. Anaplastic Large Cell Lymphoma and Breast Implants. Plastic Reconst Surg 2011; 128 (3): 629-39. https://doi.org/10.1097/PRS.0b013e31821f9f23

35. Yamaguchi M, Oguchi M, Suzuki R. Extranodal NK/T-cell lymphoma: Updates in biology and management strategies. Best Pract Clin Haematol 2018; 3(3):315-21.

https://doi.org/10.1016/j.beha.2018.07.002

36. Park S, Ko YH. Epstein-Barr virus-associated T/ natural killer-cell lymphoproliferative disorders. J Dermatol 2014; 41(1):29-39. https://doi.org/10.1111/1346-8138.12322

37. Tan SY, Ooi AS, Ang MK, et al. Nuclear expression of MATK is a novel marker of type II enteropathyassociated T-cell lymphoma. Leukemia. 2011; 25 (3): 555-7.

https://doi.org/10.1038/leu.2010.295

38. Quintanilla-Martinez, L. The 2016 updated WHO classification of lymphoid neoplasias. Hematol Oncol 2017; 35 (S1): 37-45.

https://doi.org/10.1002/hon.2399

39. Savage KJ, Harris NL, Vose JM, et al. ALKanaplastic large-cell lymphoma is clinically and immunophenotypically different from both ALK+ ALCL and peripheral T-cell lymphoma, not otherwise specified: report from the International Peripheral T-Cell Lymphoma Project. Blood 2008; 111 (12): 5496-504.

https://doi.org/10.1182/blood-2008-01-134270
40. Ferreri AJ, Govi S, Pileri SA. Hepatosplenic gamma-delta T-cell lymphoma. Crit Rev Oncol Hematol. 2012; 83 (2): 283-92. https://doi.org/10.1016/j.critrevonc.2011.10.001

41. Elin F, Landström J, Jerkeman M, Relander T. Realworld data on prognostic factors and treatment in peripheral T-cell lymphomas: a study from the Swedish Lymphoma Registry. Blood 2014; 124 (10): 1570-7.

https://doi.org/10.1182/blood-2014-04-573089

42. Schmitz N, Trumper L, Ziepert M, et al. Treatment and prognosis of mature $\mathrm{T}$-cell and NK-cell lymphoma: an analysis of patients with T-cell lymphoma treated in studies of the German HighGrade Non-Hodgkin Lymphoma Study Group S0350. Blood 2010; 116 (18): 3418-25. https://doi.org/10.1182/blood-2010-02-270785

43. Carson KR, Horwitz SM, Pinter-Brown LC, et al. A prospective cohort study of patients with peripheral T-cell lymphoma in the United States. Cancer 2017; 123: 1174-83.

https://doi.org/10.1002/cncr.30416

44. d'Amore F, Relander T, Lauritzsen GF, et al. Upfront autologous stem-cell transplantation in peripheral T-cell lymphoma: NLG-T-01. J Clin Oncol 2012; 30 (25): 3093-99. https://doi.org/10.1200/JCO.2011.40.2719

45. Schmitz N, de Leval L. How I manage T-cell lymphoma, not otherwise specified and angioimmunoblastic T-cell lymphoma: current practice and a glimpse into the future.Br J Haematol 2016; 176 (6): 851-66.

https://doi.org/10.1111/bjh.14473

46. Petković I. Current trends in the treatment of primary mediastinal large B-cell lymphoma - an overview. Contemp Oncol (Poznan) 2015; 19 (6):428-35.

https://doi.org/10.5114/wo.2015.56388

47. Maeda Y, Nishimori H, Hiramatsu Y, et al Doseadjusted EPOCH chemotherapy for untreated periheral T-cell lymphomas: Multicenter phase II 
trial of West-Jhog PTCL 0707. Haematologica 2017; 102 (12): 2097-103. https://doi.org/10.3324/haematol.2017.167742

48. Abramson JS, Feldman T, Kroll-Desrosiers AR, et al. Peripheral T-cell lymphomas in a large US multicenter cohort: prognostication in the modern era including impact of frontline therapy. Ann Oncol 2014; 25 (11): 2211-7. https://doi.org/10.1093/annonc/mdu443

49. Zinzani PL, Magagnoli M, Bendandi $M$, et al. Therapy with gemcitabine in pretreated peripheral T-cell lymphoma patients. Ann Oncol 1998; 9 (12): 1351-3. https://doi.org/10.1023/A:1008409601731

50. Mahadevan D, Unger JM, Spier CM, et al. Phase 2 trial of combined cisplatin, etoposide, gemcitabine, and methylprednisolone (PEGS) in peripheral Tcell non-Hodgkin lymphoma: Southwest Oncology Group Study S0350. Cancer 2013; 119: 371-9. https://doi.org/10.1002/cncr.27733

51. Li L, Duan W, Zhang L, et al. The efficacy and safety of gemcitabine, cisplatin, prednisone, thalidomide versus $\mathrm{CHOP}$ in patients with newly diagnosed peropheral T-cell lymphoma with analysis of biomarkers. Br J Haematol 2017; 178 (5): $772-80$.

https://doi.org/10.1111/bjh.14763

52. Horwitz S, O'Connor O, Pro B, et al. Brentuximab vedotin with chemotherapy for CD30-positive peripheral T-cell lymphoma (ECHELON-2): a global, double-blind, randomised, phase 3 trial. Lancet 2019; 393 (10168): 229-40. https://doi.org/10.1016/S0140-6736(18)32984-2

53. Advani RH, Ansell SM, Lechowicz MJ, et al. A phase II study of cyclophosphamide, etoposide, vincristine and prednisone (CEOP) Alternating with Pralatrexate $(\mathrm{P})$ as front line therapy for patients with peripheral T-cell lymphoma (PTCL): final results from the $\mathrm{T}$ - cell consortium trial. $\mathrm{Br} \mathrm{J}$ Haematol 2016; 172(4): 535-44.

https://doi.org/10.1111/bjh.13855

54. Kim SJ, Yoon DH, Kang HJ, et al. Bortezomib in combination with $\mathrm{CHOP}$ as first-line treatment for patients with stage III/IV peripheral T-cell lymphomas: A multicentre, single-arm, phase 2 trial. Eur J Cancer 2012; 48: 3223-31. https://doi.org/10.1016/j.ejca.2012.06.003

55. Pro B, Advani R, Brice $\mathrm{P}$, et al. Brentuximab vedotin (SGN-35) in patients with relapsed or refractory systemic anaplastic large-cell lymphoma: results of a phase II study. J Clin Oncol 2012; 30(18): 2190-6.

https://doi.org/10.1200/JCO.2011.38.0402

56. Zinzani PL, Venturini F, Stefoni V, et al. Gemcitabine as single agent in pretreated T-cell patients: evaluation of the long-term outcome. Ann Oncol 2010; 21(4): 860-3. https://doi.org/10.1093/annonc/mdp508

57. Damaj G, Gressin R, Bouabdallah K, et al. Results from a prospective, ope-label, phase II trial of bendamustine in refractory or relapsed T-cell lymphoma: the BENTLY trial. J Clin Oncol 2013; 31(1): 104-10.

https://doi.org/10.1200/JCO.2012.43.7285

58. Corradini P, Dodero A, Zallio F, et al. Graftversus-lymphoma effect in relapsed peripheral $\mathrm{T}$ cell non-Hodgkin's lymphomas after reducedintensity conditioning followed by allogeneic transplantation of hematopoietic cells. J Clin Oncol 2004; 22: 2172-6. https://doi.org/10.1200/JCO.2004.12.050

59. Kanakry JA, Kasamon YL, Gocke CD, et al. Outcomes of related donor HLA-identical or HLA haploidentical allogeneic blood or marrow transplantation for peripheral $\mathrm{T}$ cell lymphoma. Biol Blood Marrow Transplant 2013; 19: 602-6. https://doi.org/10.1016/j.bbmt.2013.01.006

60. Kyriakou C, Canals C, Finke J, et al. Allogeneic stem cell transplantation is able to induce longterm remissions in angioimmunoblastic $\mathrm{T}$-cell lymphoma: A retrospective study from the lymphoma working party of the European Group for Blood and Marrow Transplantation. J Clin Oncol 2009; 27: 3951-8. https://doi.org/10.1200/JCO.2008.20.4628

61. Feyler S, Prince HM, Pearce R, et al. The role of high-dose therapy and stem cell rescue in the management of T-cell malignant lymphomas: A 
BSBMT and ABMTRR study. Bone Marrow Transplant 2007; 40: 443-50. https://doi.org/10.1038/sj.bmt.1705752

62. Kim WS, Song SY, Ahn YC, et al. CHOP followed by involved field radiation: is it optimal for localized nasal natural killer/ T-cell lymphoma? Ann Oncol 2001; 12 (3): 349-52. https://doi.org/10.1023/A:1011144911781

63. Kwong YL, Kim WS, Lim ST, et al. SMILE for natural killer/T-cell lymphoma: analysis of safety and efficacy from Asia Lymphoma Study Group. Blood 2012; 120 (15): 2973-80.

https://doi.org/10.1182/blood-2012-05-431460

64. Jaccard A, Gachard N, Marin B, et al. Efficacy of L-asparaginase with methotrexate and dexamethasone (AspaMetDex regimen) in patient with refractory or relapsing extranodal NK/T-cell lymphoma, a phase 2 study. Blood 2011; 117 (6): 1834-9.

https://doi.org/10.1182/blood-2010-09-307454

65. Avila M, Aquilar H, Demichelis GR, et al. Effectiveness of L-asparaginase-based regimens compared to anthracycline-based regimens in newly diagnosed extranodal NK/T-cell lymphoma, nasal type: a single Mexican center experience. Blood Res 2018; 53 (3): 210-17.

https://doi.org/10.5045/br.2018.53.3.210

66. Bu S, Yuan F, Wei X, et al. L-asparaginase-based regimen as a first-line treatment for newly diagnosed nasal type extranodal natural killer cell/T-cell lymphoma. Exp Ther Med 2016; 11 (6): 2437-45.

https://doi.org/10.3892/etm.2016.3249

67. Yang L, Liu H, XuXH, et al. Retrospective study of modified SMILE chemotherapy for advancedstage, relapsed, or refractory extranodal natural killer (NK)/T-cell lymphoma, nasal type. Med Oncol 2013; 30 (4): 720. https://doi.org/10.1007/s12032-013-0720-7

68. Yamaguchi $\mathrm{M}$, Tobinai $\mathrm{K}$, Oguchi $\mathrm{M}$, et al. Concurrent chemoradiothreapy for localized nasal natural killer/T-cell lymphoma: an updated analysis of the Japan clinical oncology group study
JCOG0211. J Clin Oncol 2012; 30 (32): 4044-6. https://doi.org/10.1200/JCO.2012.45.6541

69. Kwong YL, Chan TSY, Tan D, et al. PD1 blockade with pembrolizumab is highly effective in relapsed or refractory NK/T-cell lymphoma failing Lasparaginase. Blood 2017; 129 (17): 2437-42. https://doi.org/10.1182/blood-2016-12-756841

70. Hari P, Raj RV, Olteanu H. Targeting CD38 in refractory extranodal natural killer cell-T-cell lymphoma. N Engl J Med 2016; 375 (15): 1501-2. https://doi.org/10.1056/NEJMc1605684

71. Kim HK, Moon SM, Moon JH, Park JE, Byeon S, Kim WS. Complete remission in CD30-positive refractory extranodal NK/T-cell lymphoma with brentuximab vedotin. Blood Res 2015; 50 (4): 2546.

https://doi.org/10.5045/br.2015.50.4.254

72. Poon LM, Kwong YL. Complete remission of refractory disseminated $\mathrm{NK} / \mathrm{T}$ cell lymphoma with brentuximab vedotin and bendamustine. Ann Hematol 2016; 95 (5): 847-9. https://doi.org/10.1007/s00277-016-2627-9

73. Malamut G, Chandesris O, Verkarre V, et al. Enteropathy associated $\mathrm{T}$ cell lymphoma in celiac disease: A large retrospective study. Dig Liver Dis 2013; 45: 377-84. https://doi.org/10.1016/j.dld.2012.12.001

74. Nijeboer, P, de Baaij, L. R., Visser, O., et al. Treatment response in enteropathy associated T-cell lymphoma; survival in a large multicenter cohort. Am J Hematol 2015; 90: 493-8.

https://doi.org/10.1002/ajh.23992

75. Jantunen E, Boumendil A, Finel H, et al. Autologous stem cell transplantation for enteropathy-associated T-cell lymphoma: a retrospective study by EBMT. Blood 2013; 121: 2529-32. https://doi.org/10.1182/blood-2012-11-466839

76. Gentille C, Qin Q, Barbieri A, et al. Use of PEGasparaginase in monomorphic epitheliotropic intestinal T-cell lymphoma, a disease with diagnostic and therapeutic challenges.

Ecancermedicalscience 2017; 11: 771. 
https://doi.org/10.3332/ecancer.2017.771

77. Voss MH, Lunning MA, Maragulia JC, et al. Intensive induction chemotherapy followed by early high-dose therapy and hematopoietic stem cell transplantation results in improved outcome for patients with hepatosplenic T-cell lymphoma: a single institution experience. Clin Lymphoma Myeloma Leuk 2013;13 (1): 8-14. https://doi.org/10.1016/j.clml.2012.09.002

78. O'Connor OA, Pro B, Pinter-Brown L, et al. Pralatrexate in patients with relapsed or refractory peripheral T-cell lymphoma: Results from the pivotal PROPEL study. J Clin Oncol 2011; 29: 1182-9. https://doi.org/10.1200/ICO.2010.29.9024

79. Qi W, Spier C, Liu X, et al. Alisertib (MLN8237) an investigational agent suppresses Aurora A and B activity, inhibits proliferation, promotes endoreduplication and induces apoptosis in T-NHL cell lines supporting its importance in PTCL treatment. Leuk Res 2013; 37(4): 434-9.

https://doi.org/10.1016/i.leukres.2012.10.017

80. Barr PM, Li H, Spier C, et al. Phase II Intergroup Trial of Alisertib in Relapsed and Refractory Peripheral T-Cell Lymphoma and Transformed Mycosis Fungoides: SWOG 1108. J Clin Oncol 2015; 33(21): 2399-404.

https://doi.org/10.1200//CO.2014.60.6327

81. Friedberg JW, Mahadevan D, Cebula E, et al. Phase II study of alisertib, a selective Aurora A kinase inhibitor, in relapsed and refractory aggressive Band T-cell non-Hodgkin lymphomas. J Clin Oncol 2014; 32(1): 44-50.

https://doi.org/10.1200//CO.2012.46.8793

82. Islam S, Vick E, Huber B, et al. Co-targeting aurora kinase with PD-L1 and PI3K abrogates immune checkpoint mediated proliferation in peripheral T-cell lymphoma: a novel therapeutic strategy. Oncotarget 2017; 8(59):100326-38. https://doi.org/10.18632/oncotarget.22222

83. Shustov A, Coiffier B, Horwitz S, et al. Romidepsin is effective and well tolerated in older patients with peripheral T-cell lymphoma: analysis of two phase II trials. Leuk Lymphoma 2017; 58 (10): 2335-41. https://doi.org/10.1080/10428194.2017.1295143

84. O' Connor OA, Falchi L, Lue JK, et al. Oral 5azacytidine and romidepsin exhibit marked activity in patients with PTCL: a multicenter phase I study. Blood 2019; e pub ahead of print https://doi.org/10.1182/blood.2019001285

85. O' Connor OA, Horwitz S, Masszi $\mathrm{T}$, et al. Belinostat in Patients With Relapsed or Refractory Peripheral T-Cell Lymphoma: Results of the Pivotal Phase II BELIEF (CLN-19) Study. J Clin Oncol 2015; 33 (23): 2492-9. https://doi.org/10.1200/JCO.2014.59.2782

86. Gambacorti Passerini C, Farina F, et al. Crizotinib in advanced, chemoresistant anaplastic lymphoma kinase-positive lymphoma patients. J Natl Cancer Inst 2014; 106(2): djt378. https://doi.org/10.1093/jnci/djt378

87. Thanarajasingam G, Edell ES, Markovic SM. Complete Response of Anaplastic Lymphoma Kinase-Mutated Refractory Extranodal Natural Killer/T-Cell Lymphoma to Crizotinib. Mayo Clin Proc 2016; 91 (9): 1319-20. https://doi.org/10.1016/j.mayocp.2016.06.014

88. Horwitz SM, Koch R, Porcu P, et al. Activity of the $P I 3 K-\delta, \gamma$ inhibitor duvelisib in a phase 1 trial and preclinical models of T-cell lymphoma. Blood 2018; 131 (8): 888-98.

https://doi.org/10.1182/blood-2017-08-802470

89. Oki Y, Haverkos B, Zain JM, et al. Tenalisib, a dual PI3K $\delta / \gamma$ inhibitor: Safety and efficacy results from an on-going phase $\mathrm{I} / \mathrm{lb}$ study in relapsed/refractory T-cell lymphoma. J Clin Oncol 2018; 36.15 suppl 7510 ASCOAbstract https://doi.org/10.1200/ICO.2018.36.15 suppl.7510

90. Delarue R, Dupuis J, Sujobert P, et al. Treatment with hypomethylating agent 5-azacytidine inducessustained response in angioimmunoblastic T cell lymphomas. Blood 2016; 128: 4164A. https://doi.org/10.1182/blood.V128.22.4164.4164

91. Makita S, Maeshima AM, Maruyama D, et al. Forodesine in the treatment of relapsed/refractory peripheral T-cell lymphoma: an evidence-based 
review. Onco Targets Ther 2018; 11: 2287-93. https://doi.org/10.2147/OTT.S140756

92. Witzig T, Sokol L, Jacobsen E, et al. Preliminary Results From An Open-Label, Phase II Study Of Tipifarnib In Relapsed Or Refractory Peripheral TCell Lymphoma. Hematol Oncol 2017; 35(S2): 251-2. https://doi.org/10.1002/hon.2438 115

93. Ogura $M$, Ishida $T$, Hatake $K$, et al. Multicenter phase II study of mogamulizumab (KW-0761), a defucosylated anti-cc chemokine receptor 4 antibody, in patients with relapsed peripheral Tcell lymphoma and cutaneous T-cell lymphoma. J Clin Oncol 2014; 32(11): 1157-63. https://doi.org/10.1200/ICO.2013.52.0924

94. Enblad G, Hagberg H, Erlanson M, et al. A pilot study of alemtuzumab (anti-CD52 monoclonal antibody) therapy for patients with relapsed or chemotherapy-refractory peripheral T-cell lymphomas. Blood 2004; 103 (8): 2920-4. https://doi.org/10.1182/blood-2003-10-3389

95. Lesokhin AM, Ansell SM, Armand P, et al. Nivolumab in Patients With Relapsed or Refractory Hematologic Malignancy: Preliminary Results of a Phase Ib Study. J Clin Oncol 2016; 34(23): 2698-704. https://doi.org/10.1200//CO.2015.65.9789

96. Amengual JE, Lichtenstein R, Rojas $C$ et al. The pralatrexate-romidepsin doublet: A well tolerated and highly effective combination for patients with relapsed or refractory peripheral T-cell lymphoma. Blood 2016; 128: 1824A. https://doi.org/10.1182/blood.V128.22.1824.1824
97. Mehta-Shah N, Lunning MA, Boruchov AM et al. A phase I/II trial of the combination of romidepsin and lenalidomide in patients with relapsed/ refractory lymphoma and myeloma: Activity in T-cell lymphoma. J Clin Oncol 2015; 33 (suppl 15): 8521A. https://doi.org/10.1200/jco.2015.33.15 suppl.8521

98. Holkova B, Yazbeck V, KmieciakMet al. A phase 1 study of bortezomib and romidepsin in patients with chronic lymphocytic leukemia/small lymphocytic lymphoma, indolent B-cell lymphoma, peripheral T-cell lymphoma, or cutaneous T-cell lymphoma. Leuk Lymphoma 2017; 58 (6): 1349-57. https://doi.org/10.1080/10428194.2016.1276287

99. Mehta-Shah N, Moskowitz AJ, Lunning M et al. A phase $\mathrm{Ib} / \mathrm{II} a$ trial of the combination of romidepsin, lenalidomide and carfilzomib in patients with relapsed/refractory lymphoma shows complete responses in relapsed and refractory T-cell lymphomas. Blood 2016; 128: 2991A. https://doi.org/10.1182/blood.V128.22.2991.2991

100. Fanale MA, Hagemeister FB, Fayad L et al. A phase I trial of alisertib plus romidepsin for relapsed/refractory aggressive $\mathrm{B}$ - and T-cell lymphomas. Blood 2014; 124: 1744A. https://doi.org/10.1182/blood.V124.21.1744.1744

101. Moskowitz AJ, Koch R, Mehta-Shah N et al. In vitro, in vivo, and parallel phase I evidence support the safety and activity of duvelisib, a PI3K- inhibitor in combination with romidepsin or bortezomib in relapsed/refractory T-cell lymphoma. Blood 2017; 130 (suppl 1): 819A. 


\title{
Nodalne i ekstranodalne periferne T/NK ćelijske neoplazme: savremeni aspekti
}

\author{
Ivan Petkovići,2, Aleksandar Popović², Miljana Džunić2 ${ }^{2}$ Ivica Pejčić1,2 \\ ${ }^{1}$ Univerzitet u Nišu, Medicinski fakultet, Departman za onkologiju, Niš, Srbija \\ ${ }^{2}$ Klinika za onkologiju, Klinički centar Niš, Niš, Srbija
}

S A ŽET AK

Periferni T/NK ćelijski limfomi (PTCL) su retki i izrazito heterogeni maligni tumori. Bolest je sklona relapsima, sa visokom stopom hemiorefraktarnosti, što vodi ka lošem ukupnom ishodu lečenja. Kod gotovo $70 \%$ bolesnika dolazi do relapsa, dok se petogodišnja stopa preživljavanja kreće oko $30 \%$. Uvodna linija lečenja PTCL je interpolirana od principa lečenja agresivnih B ćelijskih NHL. Univerzalno prihvaćena, prva linija lečenja prevashodno je palijativna. Pored maksimalnih napora da se poboljša primarni pristup, samo je period do progresije bolesti produžen, dok efekta na ukupno preživljavanje nema. Svi aktuelni vodiči ističu važnost autologne transplantacije matičnih ćelija hematopoeze (Auto-SCT), kao konsolidacije prvog povoljnog terapijskog odgovora. Primena alogene transplantacije (Allo-SCT) u prvoj remisiji i dalje nije potkrepljena medicinom baziranom na dokazima, te je $s$ toga njena upotreba indikovana kod relaps/refraktornih PTCL. Nažalost, većina bolesnika nisu kandidati za agresivne tretmane, te je preporučeni pristup ograničeno primenjiv. Imajući u vidu trenutnu situaciju, neophodni su novi terapijski agensi. Postojeći rezultati ukazuju na ukupnu lošu prognozu bolesti, međutim uvođenjem L-asparaginaze, kao i target terapije kod CD30+ entiteta, došlo je do značajnog poboljšanja lečenja pojedinih PTCL. Značajan broj novih agenasa uključen je $u$ rane faze kliničkih istraživanja, sa ohrabrujućim rezultatima. Pažnja je usmerena na rezultate tih studija, imajući u vidu da trenutno nema adekvatnih tretmana za bolesnike koji su relapsirali ili su refraktarni na primenjene terapije.

Ključne reči: T/NK ćelijski limfomi, nodalni, ekstranodalni, tretman, novi agensi 